\title{
Hepatoprotective Effects of Chitosan on Thioacetamide- Induced Liver Toxicity in Male Albino Rats
}

\author{
Shereen M.M. Yahya ${ }^{1(D)}$, Rokaya H. Shalaby ${ }^{1(D)}$, Fathia A. Mannaa ${ }^{2}$ (D), \\ Khaled G. Abdel-Wahhab ${ }^{2}$ (D), Noura R. Mohamed ${ }^{1}$ (D), Marwa E. Shabana ${ }^{3}$ (D), \\ Shereen H. B. Elwakeel ${ }^{1, *(D)}$
}

1 Zoology Department, Faculty of Women for Arts, Science and Education, Ain Shams University, Asmaa Fahmy Street, Heliopolis, Cairo; shadoo_yahya@yahoo.com (S.M.M.Y); Dean@women.asu.edu.eg (R.H.S.); noura.ibrahim@women.asu.edu.eg (N.R.M.); sherien.elwakeel@women.asu.edu.eg (S.H.B.E.)

2 Medical Physiology Department, National Research Centre, Giza, Egypt; fa.elwahid@nrc.sci.eg (F.A.M); kg.eldeen@nrc.sci.eg (K.G.A.-W);

3 Pathology Department, National Research Centre,Giza, Egypt; me.shabana@ncr.sci.eg (M.E.S.);

* Correspondence: sherien.elwakeel@women.asu.edu.eg;

Scopus Author ID 56349855600

Received: 7.02.2021; Revised: 10.03.2021; Accepted: 12.03.2021; Published: 22.03.2021

\begin{abstract}
Chitosan, a natural product derived from chitin, has attracted much attention as a promising polysaccharide compound, owing to its unique biological activities. This study was designed to explore the possible improving potential of chitosan, as a natural marine product, on liver regeneration in hepatotoxicity induced by thioacetamide in male albino rats. Fifty animals were divided into 5 groups, including the control group; a group which was injected intraperitoneally with a single dose of thioacetamide $(300 \mathrm{mg} / \mathrm{kg} \mathrm{b}$. wt) for induction of liver toxicity; a group received a diet containing 5\% chitosan for 14 days; a group received a diet containing 5\% chitosan for 14 days then they were injected with thioacetamide( $300 \mathrm{mg} / \mathrm{kg} \mathrm{b}$. wt) once, and the last group which was injected with thioacetamide $(300 \mathrm{mg} / \mathrm{kg} \mathrm{b}$. wt) once then received a diet containing $5 \%$ chitosan for 14 days. The biochemical results revealed that the intake of chitosan before or after thioacetamide intoxication improved liver markers (ALAT, ASAT, GGT, ALP, albumin) and kidney functions and also plasma TNF- $\alpha$. QRT- PCR analysis revealed that chitosan downregulated hepatic TNF- $\alpha$, survivin, and c-Myc quantitative gene expression. Moreover, chitosan improved the histological picture of the liver. This study indicated the promising action of chitosan in liver regeneration.
\end{abstract}

Keywords: thioacetamide; chitosan; liver regeneration;survivin; c-myc; tumor necrosis factor- $\alpha$.

(C) 2021 by the authors. This article is an open-access article distributed under the terms and conditions of the Creative Commons Attribution (CC BY) license (https://creativecommons.org/licenses/by/4.0/).

\section{Introduction}

Liver diseases are the most life-threatening ailments worldwide, especially in Egypt [1]. In Egypt, liver diseases are the main causes of annual deaths [2, 3]. The liver is greatly liable to toxicity due to its role in the metabolism of most xenobiotics such as drugs and foreign compounds. Fortunately, cell proliferation could help the liver to regenerate after large cellular loss $[4,5]$. Consequently, alternative treatments are essential demands to replace or be used in parallel with the current regimens. Chitosan is a promising natural polysaccharide compound. It could be obtained from the shell waste of crab, shrimp, and crawfish and the fungal cell wall.

Chitosan is a good source of dietary fiber $[6,7]$. It has numerous health benefits such as immunity regulation, antitumor activity, liver protection, anti-diabetic, antioxidant[8], antibacterial, hypolipidemic, anti-inflammatory [9], wound healing activities [10,11], and 
hepatoprotective effect [12]. Being non-toxic and having great biodegradability make great advantages for chitosan to be used in oxidative stress management [13].

Contaminated foods, environmental or chemical substances exposures in work are possible sources of toxic compounds. From those toxic compounds is thioacetamide (TAA), a broadly used sulfur-containing compound found in the environment as organic sulfur compounds and used in many technical applications [14]. Also it is used to induce liver fibrosis in rats to study the therapeutic effect of anti-fibrotic drugs [15]. Normally TAA targets the liver and hence induces hepatic injury by producing reactive oxygen species (ROS)[16,17]. The thio-sulfur group of TAA is subjected to further metabolism through the oxidase system to form acetamide and TAA-S-oxide [18]. After that, TAA-S dioxide is formed, which binds covalently to the liver macromolecules and initiates hepatic injury. This injury is in the form of centrilobular necrosis [19] and of ROS formation, which together causes cell death through oxidative stress $[10,20]$. As a single dose of TAA causes hepatocyte degeneration, inflammatory cell infiltration, and raising the level of ALP, ALT, AST [21].

Apoptosis is a normally occurring cell death mechanism used to develop and maintain healthy tissues [22]. Many diseases could be developed due to dysregulated apoptosis, such as cancer, neurodegenerative disorders, and immunodeficiency diseases. Interestingly, apoptosis itself could stimulate cell proliferation and tissue regeneration in a mechanism known as apoptosis-induced proliferation. Moreover, the apoptotic process could be blocked by a group of family proteins known as an inhibitor of apoptosis proteins (IAPs) by inhibiting caspase activity. There are eight identified members of the IAP family in the mammalian genome [23]. The most important protein in this family is survivin, the smallest member in this family. It is encoded by the BIRC5 gene located on chromosome 17 in-band 17q25.3. c-myc protein was found to be highly increased in the regeneration process of the liver [24-26]. TNF- $\alpha$ could work by two opposite mechanisms. It could act as an initiator of cell death; alternatively, it could enhance cell proliferation. Consequently, it plays an important role in the pathophysiology of viral hepatitis, alcoholic and non-alcoholic liver diseases [27,28].

The present study investigated chitosan potency in enhancing tissue regeneration against liver toxicity induced by TAA in rats. The effect of chitosan on liver functions and kidney functions was studied. Besides, the measurements of the pro-inflammatory cytokine TNF- $\alpha$ in plasma and quantitative analysis for liver tissue gene expression levels of survivin, c-Myc genes, and TNF- $\alpha$ were done. Additionally, the histobiological feature of the liver was examined.

\section{Materials and Methods}

\subsection{Chemicals.}

TAA was purchased from Aldrich Chem Co., England, as pure crystals; it was dissolved in saline and freshly prepared prior to each injection.

Chitosan (CS) was obtained from Sigma-Aldrich (molecular weight=100 KDa). Chitosan, an important polysaccharide of marine origin, is prepared from Crustaceans' shells and is being used as a new source of dietary fiber in drug development due to its intrinsic safety when taken orally [29]. 


\subsection{Experimental design.}

Fifty adult male Wistar albino rats weighing approximately 120-150 g were obtained from the Animal House Colony of the National Research Centre, Cairo, Egypt. The animals were kept in stainless steel cages under standard laboratory conditions at good ventilation and a 12-hour light-dark cycle, relative humidity of $60 \pm 5 \%$, with free access to standard commercial laboratory food and tap water.

Before the beginning of the experimental protocol, rats were adapted to experimental conditions for 2 weeks. The human care was applied according to the standard institution's criteria for the care and use of experimental animals according to the method confirmed by the Ethics Committee of the National Research Centre (FWA 00014747), which keeps track of the recommendations of the National Institutes of Health Guide for Care and Use of Animals in Laboratory (publication No. 85-23, revised in 1985).

The animals were divided into five groups after the acclimatization period (10 rats each) as follow:

Group (1): normal healthy animals served as a control group.

Group (2): (TAA) group in which the rats were intraperitoneally injected with TAA (dissolved in $0.9 \%$ normal saline) in a single dose $(300 \mathrm{mg} / \mathrm{kg} \mathrm{b}$.w ) according to Mustafa et al. [30] for induction of liver toxicity.

Group (3): chitosan group in which animals fed chitosan mixed basal diet at a ratio of $5 \%(50 \mathrm{~g}+$ 950g basal diet) according to AboZaid et al. [9] for 14 days.

Group (4): chitosan then TAA group in which animals received a diet containing $5 \%$ chitosan [9] for 14 days then intraperitoneally injected with a single dose of TAA( $300 \mathrm{mg} / \mathrm{kg} \mathrm{b.w}$ )as mentioned above.

Group (5): TAA then chitosan group in which animals were intraperitoneally injected with TAA single dose (300 mg/kg b. w ) as mentioned above, then fed a diet containing $5 \%$ chitosan for 14 days.

Each animal's body weight was recorded every week and at the end of the experiment to monitor body weight change. At the end of the experimental period, animals have fasted 12 hours. Then they were anesthetized via inhalation of diethyl ether; blood samples were withdrawn from retro-orbital venous plexus in centrifuge tubes using heparinized sterile glass capillaries.

For the separation of plasma, a part of all blood samples was assembled on EDTA, the other part was assembled in a tube which is free from anticoagulant in order to separate the serum. Both serum and plasma samples were separated by using cool-centrifugation at 3000 rpm for 15 minutes at $4{ }^{\circ} \mathrm{C}$. Aliquots of plasma and serum were preserved at $-20^{\circ} \mathrm{C}$ for biochemical analysis.

As soon as the blood is collected, the animals were sacrificed by cervical decapitation. The liver of each rat was removed and thoroughly washed by using isotonic saline, dried, and divided into two sections; the first section was snap-frozen directly in liquid nitrogen and preserved at $-80^{\circ} \mathrm{C}$ prior to RNA isolation for gene expression analysis. In contrast, the second portion was fixed in formal-saline $(10 \%)$ to be used in histopathological examination.

\subsection{Biochemical analysis.}

Serum aspartate aminotransferase (ASAT), alanine aminotransferase (ALAT), alkaline phosphatase (ALP), and gamma-glutamyl transferase (GGT) activities, as well as albumin, 
urea, and creatinine levels, were estimated spectrophotometrically using reagent kits purchased from bio-diagnostic Co., Egypt. Plasma tumor necrosis factor-alpha (TNF- $\alpha$ )concentration was estimated via ELISA technique using a rat TNF- $\alpha$ ELISA kit purchased from Glory Science Co., Ltd., USA.

\subsection{Gene expression analysis.}

Using a quantitative analysis (Real-Time PCR), expression of survivin, c-Myc, and TNF- $\alpha$ genes was determined in liver tissue samples.

\subsubsection{RNA Isolation, Clean Up and Quantitative Real-Time RT-PCR.}

RNA was isolated from $100 \mathrm{mg}$ liver tissue sample by Qiazol buffer (Qiagen, USA); RNA was subsequently cleaned up using RNAeasy mini Kit (Qiagen, USA); RNA was reverse transcribed, and the resulting cDNA was then amplified. $\beta$-actin, survivin, c-myc, and TNFalpha genes copy numbers were quantified using QuantiFast Sybergreen RT-PCR kit(Qiagen, USA). All samples were run in triplicate, and the copy numbers were normalized to 100,000 copies of the housekeeping beta-actin gene. Primer sequences are listed in Table 1. The RT and subsequent PCR cycling conditions were as follows, $50^{\circ} \mathrm{C}$ for $10 \mathrm{~min}, 95^{\circ} \mathrm{C}$ for $5 \mathrm{~min}, 95^{\circ} \mathrm{C}$ for $15 \mathrm{~s}$, then $60^{\circ} \mathrm{C}$ for $30 \mathrm{~s}$, the number of cycles was 40 cycles. MiniOpticonTM Bio-Rad RealTime Thermal Cycler was used for gene expression quantization.

Table 1. Sequences of the primers used in the RT-PCR analysis.

\begin{tabular}{c|c|c} 
Target gene & Forward primer $\left(\mathbf{5}^{\prime} \mathbf{-} \mathbf{3}^{\prime}\right)$ & Reverse primer $\left(\mathbf{5}^{\prime} \mathbf{-} \mathbf{3}^{\prime}\right)$ \\
\hline$\beta$-actin (housekeeping gene) & CCTTCCTGGGCATGGAGTCCT & GGAGCAATGATCTTGATCTTC \\
\hline survivin & CTTCATCCACTGCCCTACCG & CAGGGGAGTGCTTCCTATGC \\
\hline c-MYC & GTCCTCAAGAGGTGCCATGT & CTCGCCGTTTCCTCAGTAAG \\
\hline TNF- $\alpha$ ) & ACTGAACTTCGGGGTGATTG & GCTTGGTGGTTTGCTACGAC
\end{tabular}

\subsection{Histopathological examination.}

After the fixation of liver tissues in $10 \%$ formal-saline for twenty-four hours, tissue samples were washed in current tap water; then subjected to dehydration using ethyl (serial dilutions upward to absolute ethyl). Specimens were cleared in xylene and embedded in paraffin at $56^{\circ} \mathrm{C}$ in a hot air oven for 24 hours. The wax-tissue blocks were prepared for sectioning at 4 microns thickness by sludge microtome. The sections were deparaffinized, stained by hematoxylin and eosin, and finally investigated via an electric light microscope [31].

\subsection{Statistical analysis.}

Data were analyzed using version 13 of the computer-based statistical package for social sciences. Results are expressed as means \pm SD of three independent experiments. Statistical significance of difference was determined using one-way analysis of variance (ANOVA) followed by LSD post hoc comparisons test at $p \leq 0.05$, which was defined as statistically significant. 


\section{Results and Discussions}

\subsection{Results.}

The data presented in Figure 1 showed that the body weight gain of the TAA intoxicated animals' group was significantly decreased (-308.5\%), while that of the chitosan only group showed significant change $(50 \%)$ when both groups were compared to the control group. Interestingly, the chitosan then TAA animals' group showed a significant rise $(289.7 \%)$ in the body weight gain; similarly, TAA then chitosan animals' group showed a significant increase $(239.56 \%)$ in the bodyweight gain when both groups were compared with the TAA intoxicated animals' group.

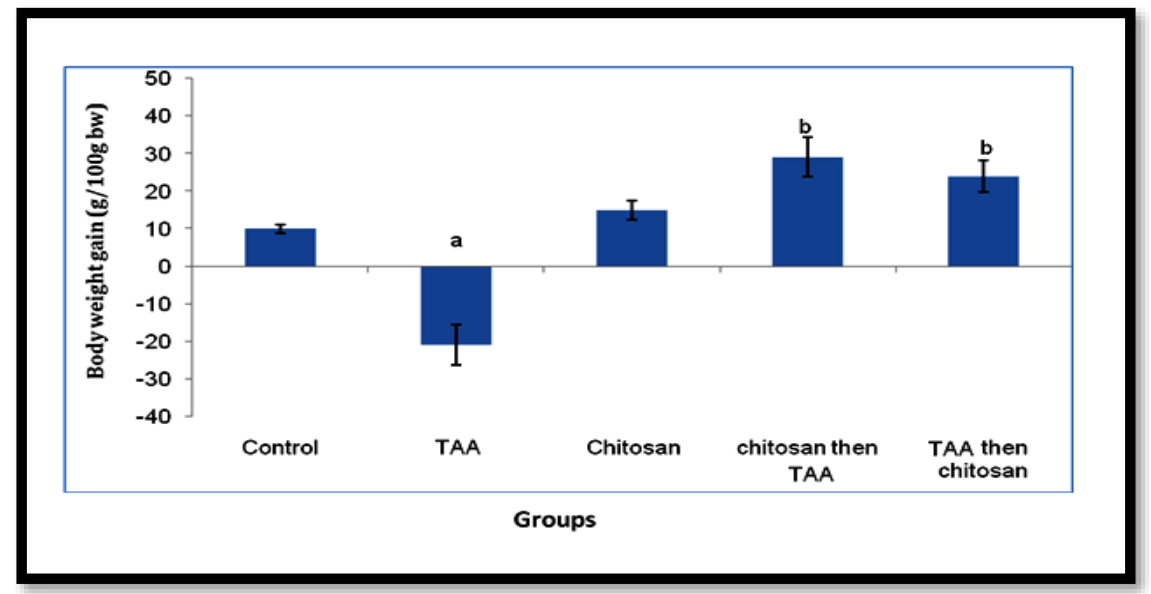

Figure 1. Bodyweight gain (\%) of control, thioacetamide, and chitosan-fed animals' groups. The superscript (a) is a significant difference from the control group; the superscript (b) is a significant difference from the TAA group.

Regarding liver function tests, feeding of normal rats with 5\% chitosan-basal diet for 14 days neither disturb liver or renal function tests reflecting their safe effect at that concentration in the diet; contrary, TAA-induced liver toxicity in rats significantly increased $(94.47 \%)$ the activity of serum aspartate aminotransferase (ASAT) compared with the control group. However, a significant decrease (-32\% and - $15.4 \%$ ) in serum ASAT activity was recorded in both chitosan fed-regimens (chitosan-TAA and TAA-chitosan groups, respectively) as compared to the TAA-intoxicated group. A significant increase $(91.89 \%)$ in serum alanine aminotransferase (ALAT) activity was recorded in the TAA group compared to the control group. In a promising effect, chitosan then TAA and TAA then chitosan groups led toa significant decrease (- $40.8 \%$ and $32.3 \%$, respectively) in serum (ALAT) activity as compared to the TAA group. Similarly, a significant increase $(232.9 \%)$ in serum alkaline phosphatase (ALP) activity was detected in the TAA-intoxicated animals' group compared to the control group. Favorably, feeding of rats with a chitosan mixed diet for 14 days before intoxication withTAA resulted in a significant decrease(-54.06\%) in serum ALP activity; also, a significant reduction (- 50.6\%) in serum ALP activity was recorded in the animals' group that fed chitosan mixed diet post-TAA-intoxication when both animals' groups were compared with the group treated only with TAA.

With respect to the activity of serum gamma Glutamyltransferase(GGT), TAA-induced liver toxicity significantly increased $(223.5 \%)$ the activity of serum GGT, while the chitosanonly treated animals' group did not deteriorate its activity when both groups were compared with that of the control group. Interestingly, feeding of animals on a chitosan mixed diet before 
TAA-intoxication showed a significant reduction (-50.28 \%) in serum GGT activity; similarly, a significant decrease $(-41.0 \%)$ in GGT activity was noticed in the animals' group that intoxicated with TAA before fed on chitosan mixed diet when both were compared with the TAA-intoxicated group. Serum albumin level was significantly decreased (-36.58\%) after TAA injection (TAA group), while, chitosan group revealed insignificant change $(2.4 \%)$ in serum albumin level when both groups were compared with the control group. However, feeding the animals with chitosan at different regimens, either before or after TAA-intoxication, revealed a significant elevation (50\% and 38.4\%, respectively) in serum albumin level when both were compared with the TAA group (Table 2).

With respect to renal function testes (Table 2), a significant rise ( $82.67 \%$ and $232.77 \%$ ) was observed in both urea and creatinine serum levels, respectively, in the TAA-intoxicated group; meanwhile, chitosan-only treated group showed insignificant change $(19.3 \%$ and -15 $\%$, respectively) when both groups were compared with the control group. In a promising manner, chitosan then TAA animals' group showed a significant decrease $(-36.04 \%$ and $45.2 \%$ ) in serum levels of urea and creatinine, respectively, when compared with the TAA group. Moreover, feeding of the rats on a chitosan mixed diet for 14 days after TAAintoxication illustrated a significant decrease $(-30.6 \%$ and $-35.10 \%)$ in serum levels of both urea and creatinine, respectively when both groups were compared with the TAA-treated animals' group.

Table 2. Liver and kidney function tests of control,TAA, and chitosan-fed animals' groups.

\begin{tabular}{|c|c|c|c|c|c|c|c|}
\hline Parameters & $\begin{array}{l}\text { ASAT } \\
(\mathrm{U} / \mathrm{ml})\end{array}$ & $\begin{array}{l}\text { ALAT } \\
(\mathbf{U} / \mathbf{m l})\end{array}$ & $\begin{array}{l}\text { ALP } \\
(\mathbf{U} / \mathbf{m l})\end{array}$ & $\begin{array}{l}\text { GGT } \\
\text { (U/ml) }\end{array}$ & $\begin{array}{c}\text { Albumin } \\
\text { (g/dl) }\end{array}$ & $\begin{array}{l}\text { Urea } \\
(\mathrm{mg} / \mathrm{dl})\end{array}$ & $\begin{array}{l}\text { Creatinine } \\
\text { (mg/dl) }\end{array}$ \\
\hline Control & $47 \pm 1.3$ & $37 \pm 2.2$ & $255 \pm 6.9$ & $11.9 \pm 0.2$ & $4.1 \pm 0.02$ & $20.2 \pm 1.9$ & $1.19 \pm 0.01$ \\
\hline $\begin{array}{l}\text { TAA } \\
\%\end{array}$ & $\begin{array}{l}91.4 \pm 2.7^{\mathrm{a}} \\
94.47 \%\end{array}$ & $\begin{array}{l}71 \pm 2.5^{\mathrm{a}} \\
91.89 \%\end{array}$ & $\begin{array}{c}849 \pm 2.6^{\mathrm{a}} \\
232.9 \%\end{array}$ & $\begin{array}{c}38.5 \pm 1.6^{\mathrm{a}} \\
223.5 \%\end{array}$ & $\begin{array}{c}2.6 \pm 0.3^{a} \\
-36.58 \%\end{array}$ & $\begin{array}{c}36.9 \pm 2.5^{\mathrm{a}} \\
82.67 \%\end{array}$ & $\begin{array}{l}3.96 \pm 0.16^{\mathrm{a}} \\
232.77 \%\end{array}$ \\
\hline $\begin{array}{l}\text { Chitosan } \\
\%\end{array}$ & $\begin{array}{c}45.2 \pm 2.3 \\
-3.8 \%\end{array}$ & $\begin{array}{c}35.2 \pm 1.0 \\
-4.86 \%\end{array}$ & $\begin{array}{c}243 \pm 12.1 \\
-\% 4.7 \% \\
\end{array}$ & $\begin{array}{c}12.6 \pm 0.4 \\
5.88 \%\end{array}$ & $\begin{array}{c}4.2 \pm 0.2 \\
2.4 \%\end{array}$ & $\begin{array}{c}24.1 \pm 1.9 \\
19.3 \%\end{array}$ & $\begin{array}{c}1.01 \pm 0.03 \\
-15 \% \\
\end{array}$ \\
\hline $\begin{array}{l}\text { Chitosan then TAA } \\
\%\end{array}$ & $\begin{array}{c}62.0 \pm 3.2^{\mathrm{b}} \\
-32 . \% \\
\end{array}$ & $\begin{array}{c}42.0 \pm 2.7^{\mathrm{b}} \\
-40.8 \% \\
\end{array}$ & $\begin{array}{c}390 \pm 14.2^{\mathrm{b}} \\
-54.06 \% \\
\end{array}$ & $\begin{array}{l}19.14 \pm 0.6^{\mathrm{b}} \\
-50.28 \% \\
\end{array}$ & $\begin{array}{c}3.9 \pm 0.21^{\mathrm{b}} \\
50 \%\end{array}$ & $\begin{array}{c}23.6 \pm 1.1^{\mathrm{b}} \\
-36.04 \%\end{array}$ & $\begin{array}{c}2.17 \pm 0.2^{\mathrm{b}} \\
-45.2 \%\end{array}$ \\
\hline $\begin{array}{l}\text { TAA then chitosan } \\
\%\end{array}$ & $\begin{array}{c}77.3 \pm 4.9^{\mathrm{b}} \\
-15.4 \%\end{array}$ & $\begin{array}{c}48 \pm 1.8^{\mathrm{b}} \\
-32.3 \%\end{array}$ & $\begin{array}{l}416 \pm 1.8^{\mathrm{b}} \\
-50.6 \%\end{array}$ & $\begin{array}{l}22.7 \pm 1.6^{\mathrm{b}} \\
-41.0 \%\end{array}$ & $\begin{array}{c}3.6 \pm 0.22^{\mathrm{b}} \\
38.4 \%\end{array}$ & $\begin{array}{c}25.6 \pm 1.5^{\mathrm{b}} \\
-30.6 \%\end{array}$ & $\begin{array}{c}2.57 \pm 0.1^{\mathrm{b}} \\
-35.10 \%\end{array}$ \\
\hline
\end{tabular}

All data are expressed as (\% change) mean \pm SEM for 10 rats/ group. Data were subjected to one-way ANOVA followed by a post hoc LSD test at $\mathrm{p} \leq 0.05$. Superscript (a) is a significant difference from the control group; the superscript (b) is a significant difference from the TAA group.

As illustrated in figure (2), a significant elevation (98.26\%) was recorded in the tumor necrosis factor alfa(TNF- $\alpha$ ) level of the TAA-intoxicated animals' group; while the chitosan group showed insignificant change (-2.6\%) in plasma TNF- $\alpha$ level when both animals' groups were compared with the control group. In a favorite way, feeding the animals with chitosan mixed diet at different regimens, either before or after TAA-intoxication, revealed a significant decrease ( $-36.6 \%$ and $-31.57 \%$, respectively) in plasma level of TNF- $\alpha$ when both were compared with the TAA group. 


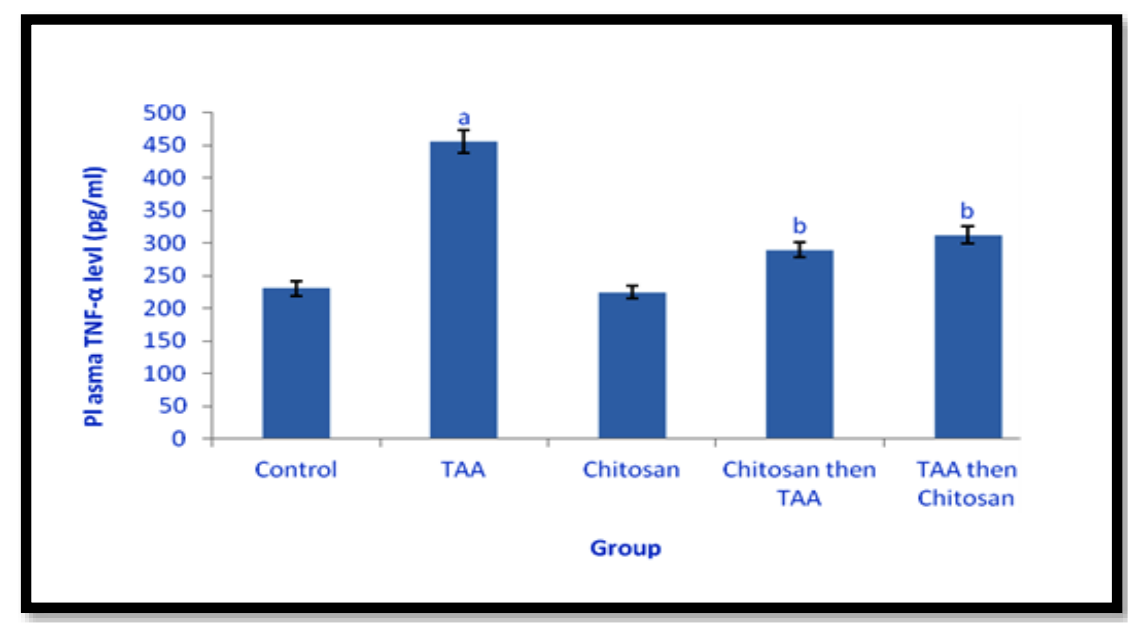

Figure 2. Plasma level of tumor necrosis factor alfa (TNF- $\alpha$ ) of control, thioacetamide, and chitosan-fed animals' groups. Data are expressed as mean \pm SEM (10 rats/group). Data were subjected to one-way ANOVA followed by a post hoc LSD test at $p \leq 0.05$. The superscript (a) is a significant difference from the control group; the superscript (b) is a significant difference from the TAA group.

\subsubsection{Gene expression.}

As illustrated in Figure 3, the TAA-intoxicated animals' group showed a significant reduction $(-81 \%)$ in survivin liver gene expression, while the chitosan-alone group performed insignificant changes in survivin liver gene expression when both groups were compared with the control group. Unfortunately, both chitosan, then TAA, and TAA, then chitosan treated animals' groups did not show any markable changes $(1.27 \%$ and $-3.2 . \%$, respectively) in that gene expression as compared to the TAA-intoxicated animals group.

Regarding c-myc gene expression, the chitosan-only group showed a significant elevation (400\%). However, the TAA-intoxicated animals' group didn't affect $(0.0 \%)$ the expression of that gene when both groups were compared to the control group. Additionally, both chitosan, then TAA, and TAA then chitosan groups showed a significant increase $(300 \%$ $\$ 700 \%$, respectively) in c-myc gene expression levels compared to the TAA group (Figure 4).

The data revealed that the animals' group treated with chitosan only recorded a marked elevation (73.33 \%)in hepatic TNF- $\alpha$ gene expression level; moreover, the TAA-intoxicated animals' group showed a significant elevation (368.3\%)when comparing both groups with the control group. This elevation was reduced significantly (-66.5\% \&-57.3\%, respectively) with chitosan treatment, either before or after TAA-intoxication, compared with the TAA animals' group (Figure 5).

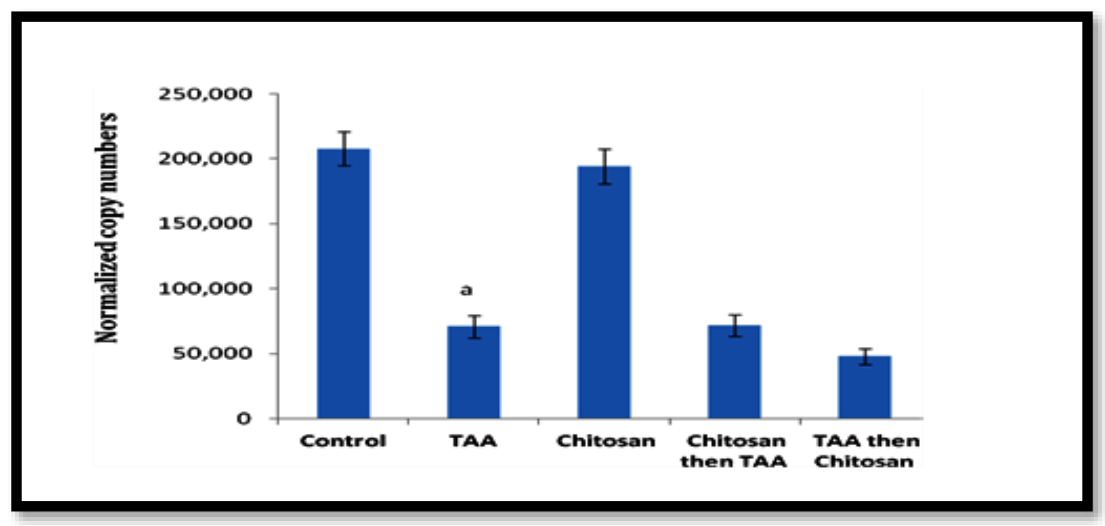

Figure 3. Liver survivin gene expression levels of control, thioacetamide, and chitosan-fed animals' groups. Results are expressed as means \pm SEM for 10 rats/group. Data were subjected to one-way ANOVA followed by

a post hoc LSD test at $\mathrm{p} \leq 0.05$. Superscript (a) letter is a significant difference from the control group. 


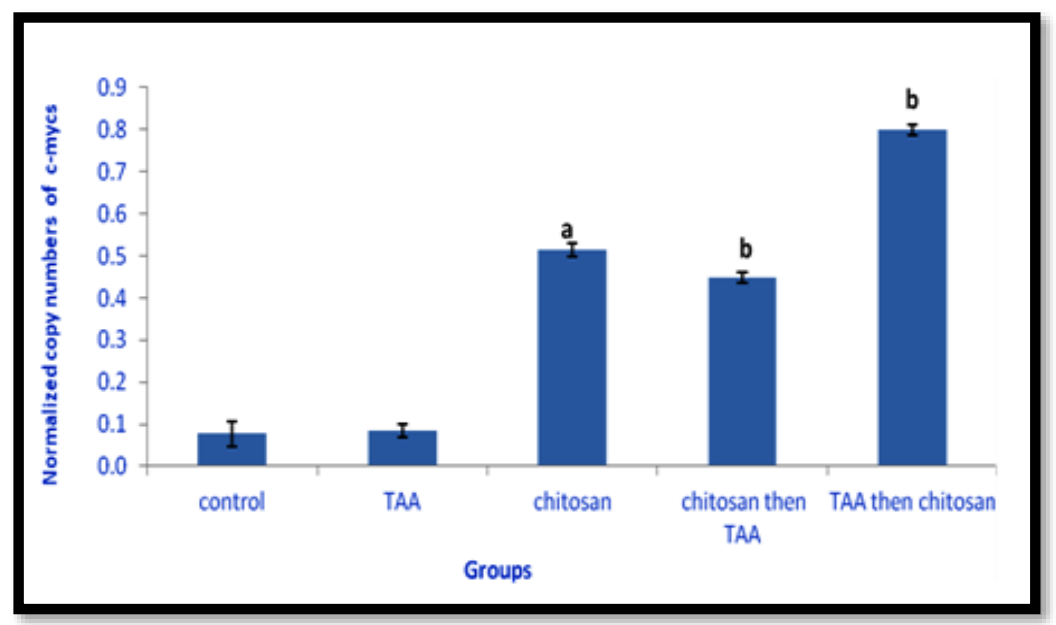

Figure 4. Liver c-myc gene expression levels of control, thioacetamide, and chitosan-fed animals' groups. Results are expressed as means \pm SEM (10 rats/group). Data were subjected to one-way ANOVA followed by a post hoc LSD test at $p \leq 0.05$. The superscript (a) is a significant difference from the control group; the superscript (b) is a significant difference from the TAA group.

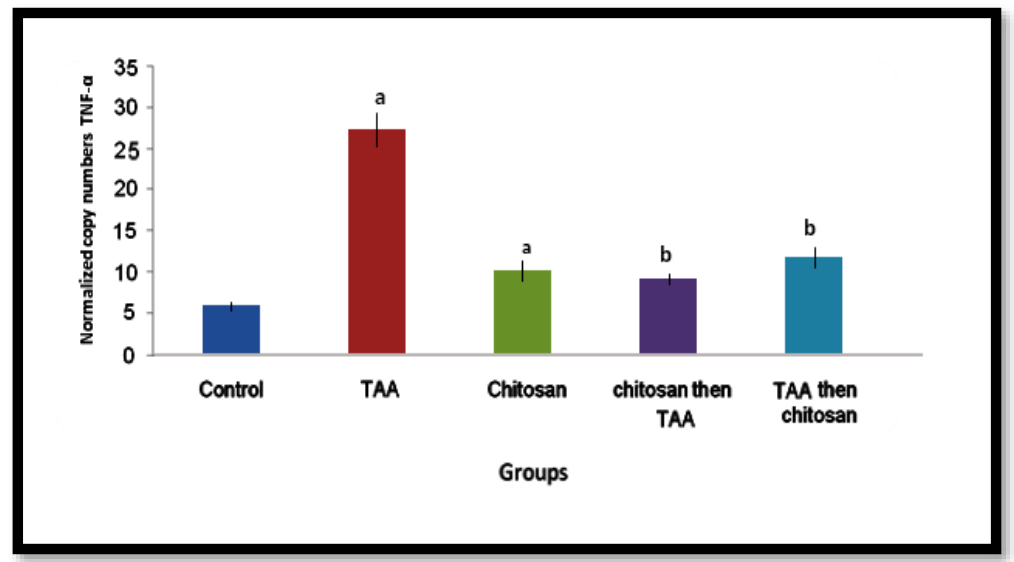

Figure 5. Liver tumor necrosis factor alfa (TNF- $\alpha)$ gene expression levels of control, thioacetamide, and chitosan-fed animals' groups. Results are expressed as means \pm SEM (10 rats/ group). Data were subjected to one-way ANOVA followed by a post hoc LSD test at $p \leq 0.05$. The superscript (a) is a significant difference from the control group; the superscript (b) is a significant difference from TAA group.

\subsubsection{Histological finding.}

The normal control group showed normal liver tissue architecture with the normal central vein, preserved portal tract with minimal inflammatory cells, and mostly normal hepatocytes (Figure 6). Meanwhile, the TAA group investigations revealed hepatic deteriorations represented by vacuolated hepatocytes cells, dilated congested central vein, dilated congested portal tract, and moderated scattered inflammatory cells (Figure 7). The chitosan drug groups demonstrated normal liver tissue architecture with slightly dilated, central, normal portal tract with minimal inflammatory cells and normal hepatocytes (Figure 8). Chitosan then TAA group revealed distorted dilated central vein, scattered inflammatory cells and dilated congested sinusoidal spaces, marked degeneration of hepatocytes with fatty changes, and increased hepatocytes' thickness (more than 2 cells thick) (Figure 9). Besides, TAA then chitosan group demonstrated congested dilated central vein scattered inflammatory cells, marked dilated congested portal tract, and scattered degenerated hepatocytes (Figure 10). 

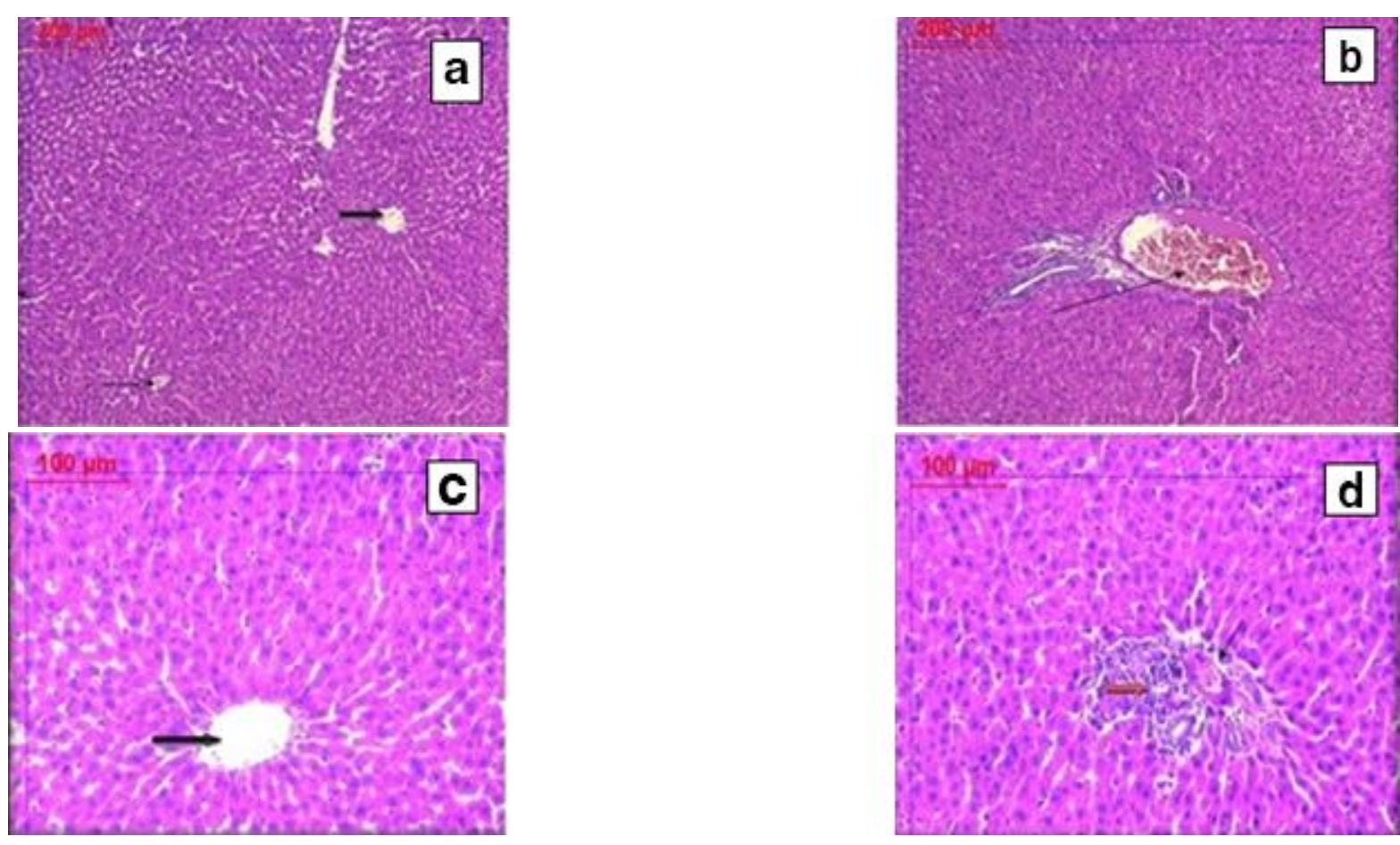

Figure 6. Photomicrography of normal control liver sections of rats stained with H\&E showed (a\&c) normal central vein (thick black arrow); (b) preserved portal tract (thin black arrow); (d) foci of inflammatory cells (thick red arrow) (H\&E 100,200).
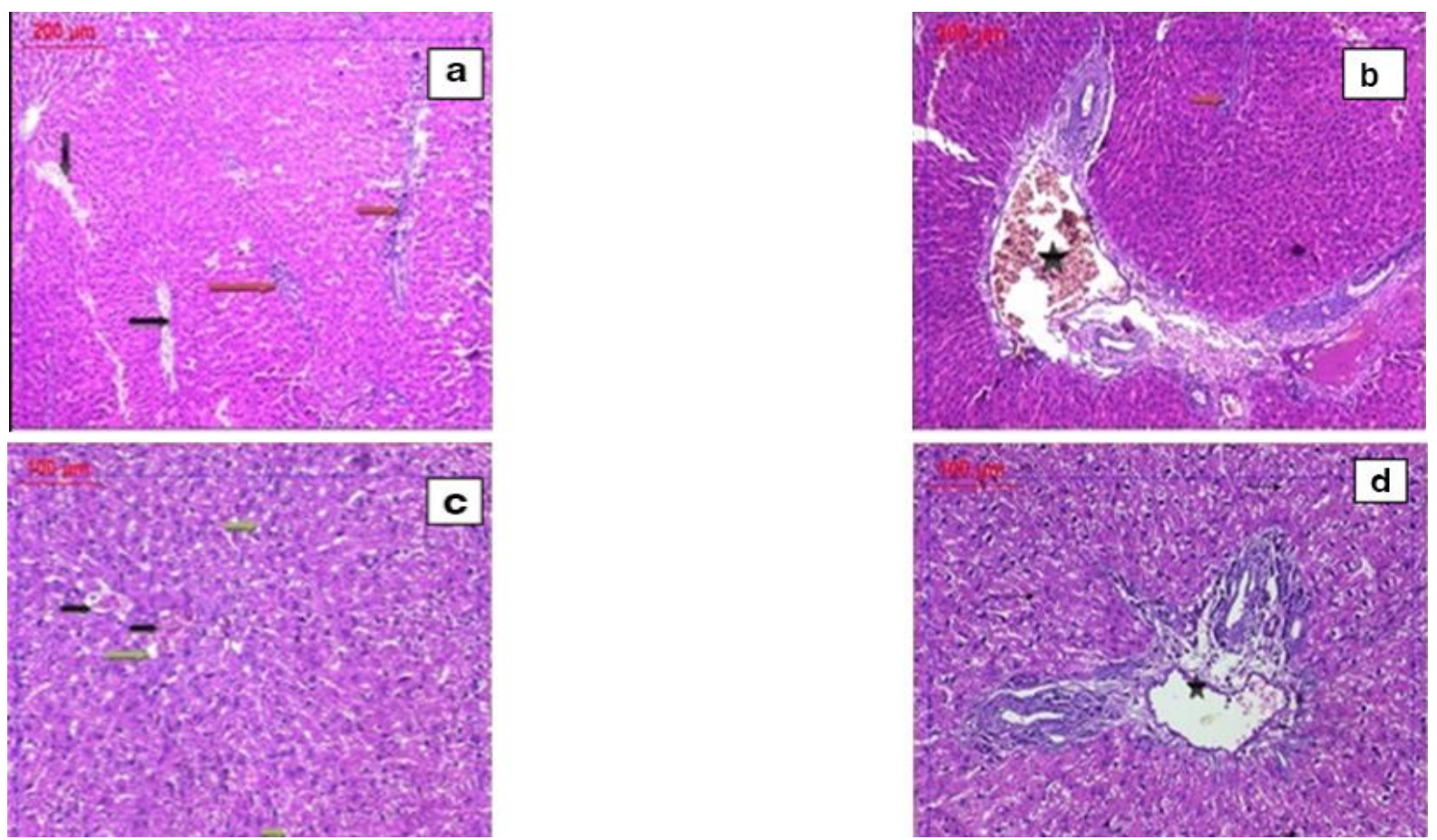

Figure 7. Photomicrography of the liver tissue of rats intoxicated intraperitoneally with thioacetamide, showing hepatic distortion in the form of (a) moderate inflammatory cells (thick red arrow); (b\&d) dilated congested portal tract surrounded by multiple scattered inflammatory cells (black star); (c) scattered multiple vacuolated hepatocytes (thick green arrow) and dilated congested central veins (thick black arrow) (H\&E 100,200). 

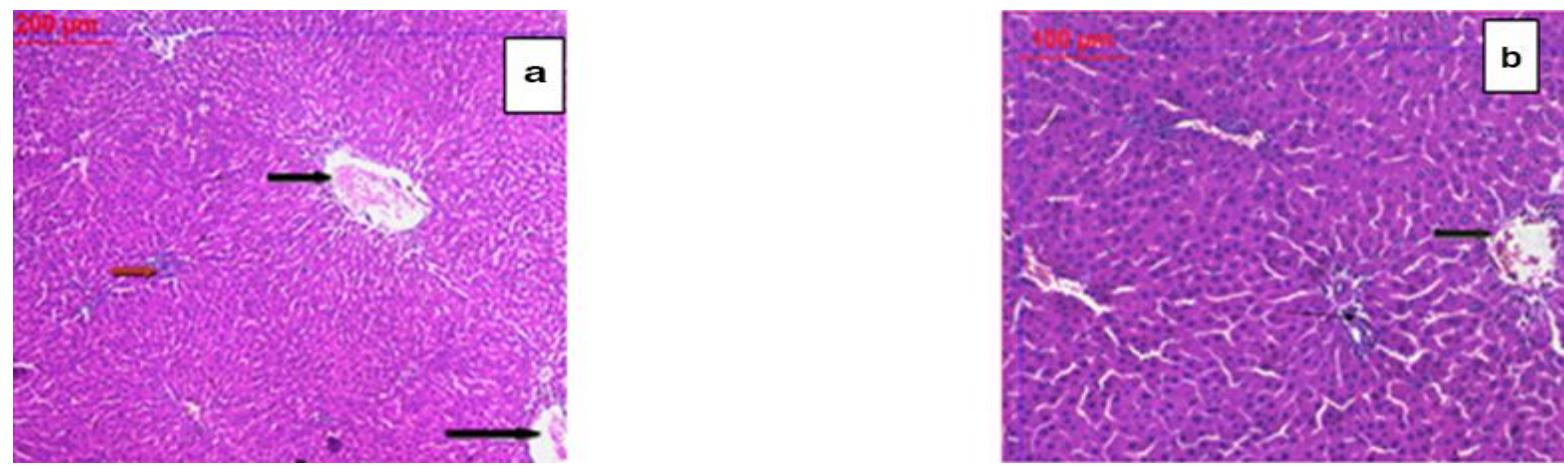

Figure 8. Photomicrography of hepatic transversal section of rats fed 5\% chitosan mixed diet for 14 days showing: (a) normal liver tissue architecture with the slightly dilated central vein (thick black arrow), normal portal tract with minimal inflammatory cells, and normal hepatocytes (thick red arrow); (b) dilated congested central vein (thick black arrow) ( H\&E 100, 200).
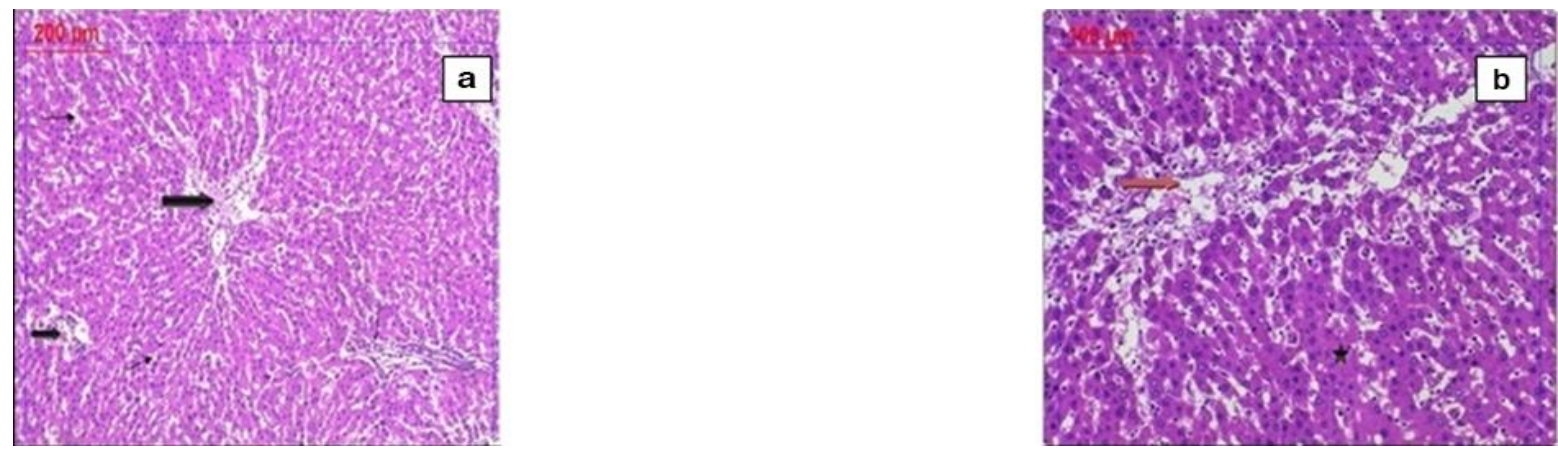

Figure 9. Photomicrography of hepatic transversal section of rats fed 5\% chitosan mixed diet for 14 days before intoxicated (ip) withTAA showing: (A) distorted dilated central vein (thick black arrow), dilated congested sinusoidal spaces, and scattered inflammatory cells (thin black arrow); (B) marked degeneration of hepatocytes (stare) with fatty changes (thick red arrow) and increase the thickness of hepatocytes (more than 2 cells thick)

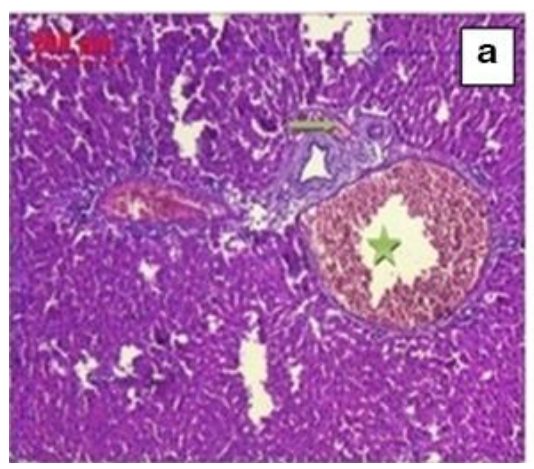

(H\&E 100, 200).
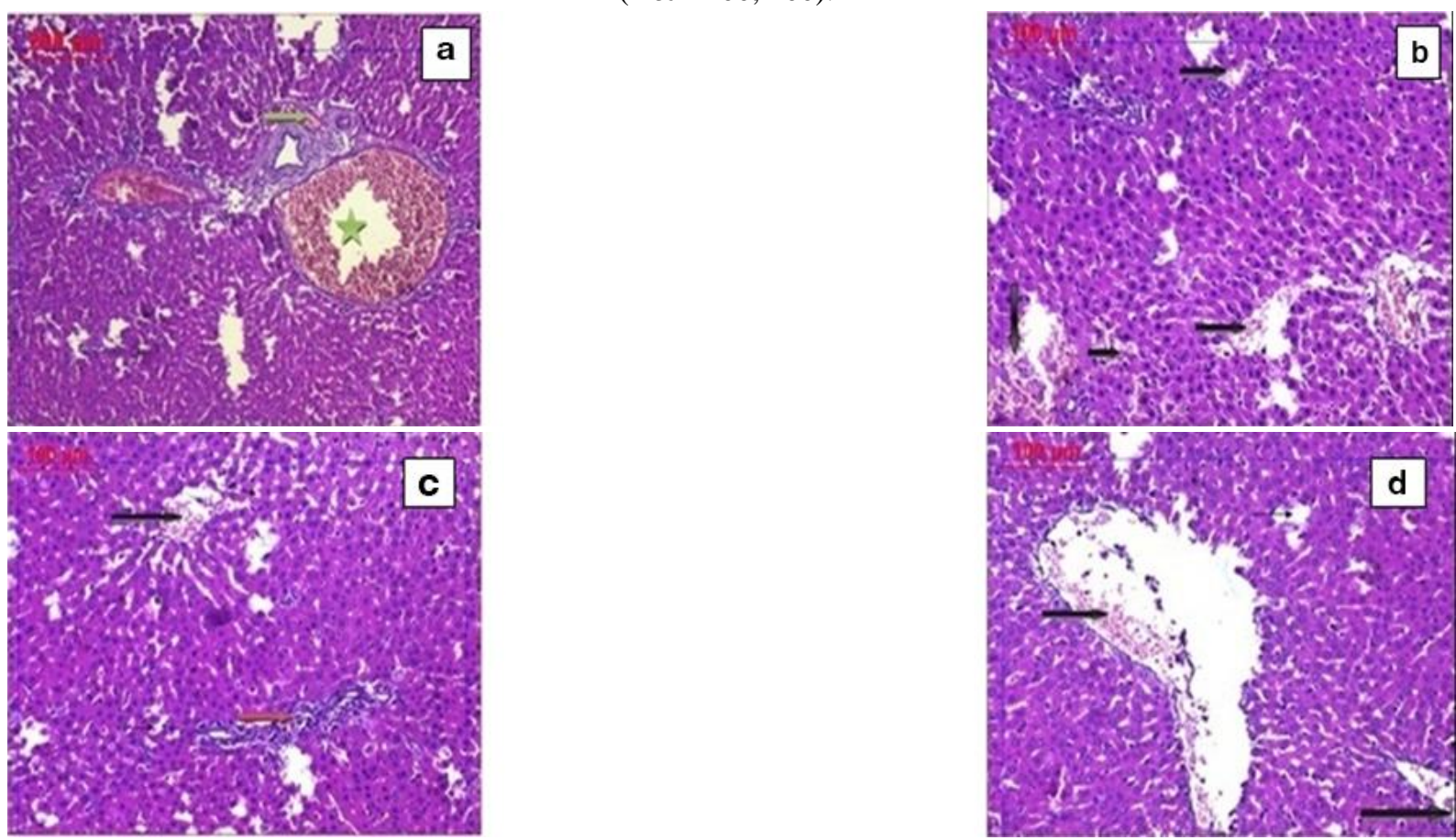

Figure 10. Photomicrography of hepatic transversal section of rats fed 5\% chitosan mixed diet for 14 days after intoxicated (ip) with TAA showing: (a) marked dilated congested portal tract (green stare) and scattered congested degenerated hepatocytes (green arrow); (b) dilated central vein (thick black arrows); (c) scattered inflammatory cells (red arrow) and dilated central vein (black arrow); (d) marked dilated congested central vein (thick black arrow) (H\&E 100, 200). 


\subsection{Discussion.}

The liver represents the largest gland in the body, where it controls many biological processes that require energy, such as metabolism, biosynthesis, excretion, secretion, and detoxification. These great energy demands make the liver a highly oxygen-dependent tissue. After a massive cellular loss, cell proliferation helps in liver regeneration. However, regeneration may fail if the loss exceeded certain limits, resulting in hepatic failure and finally death [32].

Many studies were conducted to test antioxidants' effects for ameliorating liver diseases and supporting the normal liver. Antioxidants have emerged as a therapeutic option for treating and preventing lifestyle-related diseases. However, it needs further studies to elucidate its mode of action [33,34]. Chitosan (CS) is a valuable marine polysaccharide that is obtained from the shells of some crustaceans. It has many well-established biological benefits such as immunity regulation, antitumor, liver protection, anti-diabetic, antibacterial, antioxidant, anti-obesity, wound-healing actions, and hypolipidemic effect [5].

The present study investigatedthe protective and therapeutic efficacy of chitosan in enhancing tissue regeneration inTAAinduced liver toxicity in rats. TAA is traditionally used to induce liver injury in experimental animal models $[15,35]$. The toxic effect of TAA is due to its metabolites like acetamide, sulfate, and sulfoxide-derived components. This metabolite causes structural deformations of the structural proteins and enzymes, resulting in their inactivation. By its role, TAA metabolite alters cell permeability, increases nuclear volume, concentrates intracellular calcium, and inhibits mitochondrial activity, and consequently results in cell death. Due to this metabolite, the leukotrienes, as a potent inflammatory mediator secreted by the hepatic cells, are impaired [36].

In this study, treatment with chitosan influenced the liver enzymes positively. In contrast and as expected effects of TAA intoxication, the activities of serum ASAT, ALAT, ALP, and GGT showed a significant increase in the TAA-treated group compared with normal control. These results are in agreement with Baskaran et al. [37], Jain and Singhai [38,39], Osama et al. [40], who linked the elevation in serum transaminases' activities with the oxidative stress and lipid peroxidation that is a result of the toxic effect of TAA where lipid, protein, and DNA are damaged by the action of free radical resulting in hepatocellular insult and necrosis. Normally, necrotic cells discharge their contents into the bloodstream resulting in transaminases' activity increase. On the other hand, protective and curative groups treated with chitosan showed a clear downregulation in ALAT, ASAT, ALP, and GGT activities which could be attributed to antioxidant, immunomodulation, and/or wound healing and liver protection of chitosan [9]. Similarly, serum albumin level was reduced in TAA-intoxicated rats as a result of hepatic dysfunction of protein synthesis due to the impaired endoplasmic reticulum and mitochondria of hepatocytes. However, this level was up-regulated and normalized with chitosan-treatment either in protective or curative groups.

TAA-intoxication led to renal function insufficiency as serum urea, and creatinine levels were increased; this deterioration has agonized with Begum et al. [41], who reported that tubular injury in acute tubular necrosis is mainly in charge of the reduced glomerular filtration. It was also suggested that the tubular abnormalities involved are blockage of tubules, causing a backward flow of the glomerular filtrate. Thus, renal alteration in TAA-treated rats might be due to the deleterious effects of ROS. However, this increase was reversed upon chitosan treatment as either a protective or curative treatment. This observation is in accordance with 
that of Mohamed [42], who reported that chitosan ingestion significantly reduced urea and creatinine levels in renal failure patients and attributed this effect to one or two possible mechanisms: the first one is the activation of renal function for clearance of nitrogen metabolite resulting in urea and creatinine reduction, whereas the second possibility is that chitosan combines with nitrogen metabolite in the digestive tract and then excreted out resulting in urea and creatinine reduction.

In the current study, the acute toxicity of TAA significantly reduced survivin gene expression in liver tissue compared to the control group. However, feeding animals on a chitosan-mixed basal diet, as a drug control and as a protective treatment before TAA toxicity, resulted in a non-significant increase in survivin gene expression levels. Survivin has a wellestablished function in the cell cycle G2/M phase; during cell division, survivin compromises a subunit of the chromosomal passenger complex [43,44]. Survivin is expressed in normal proliferating and regenerating tissues and was reported to suppress apoptosis and help in cell cycle progression [45]. Survivin expression was found to have a positive association with the number of hepatocytes in regenerating liver. This may be explained by the finding that survivin is involved in sister chromatid separation during mitosis [46]; these facts may interpret the reduction in survivin gene expression here in post-TAA-intoxication. Hagemann et al. [46] reported that when survivin expression is reduced, localization of chromosomal passenger complex members is interrupted, and hence, with reduced Aurur B activity, centromeric target proteins phosphorylation and cytokinesis processes are impaired.

In previous studies in rodents, survivin expression was significantly increased following partial hepatectomy and post-operative. Moreover, survivin expression was found to be increased in the graft in human liver transplantation. Both in rodents and humans, survivin overexpression is associated with proliferation and not with apoptosis; consequently, survivin is important in hepatocyte proliferation and mitosis, not only in regeneration but also during normal development [46].

TAA-induced acute toxicity did not markedly affect c-myc gene expression level in liver tissue. Indeed, chitosan treatment as drug control, protective or curative treatment significantly and dramatically up-regulated c-myc gene expression level. It was reported that developmental and mitogenic signals in normal, non-transformed cells regulate c-myc expression [47]. The principal roles of c-myc are to enhance cell proliferation and to hinder cell differentiation. Cell-cycle progression was found to be enhanced by c-mycvia regulating many cell cycle controlling proteins such as cyclins (D, E, A, and B1), cyclin-dependent kinases (CDK1, 2, 4, 6), besides E2F transcription factors. On the other side, c-myc was found to suppress cell-cycle blockers' activity, such as p15, p21, and p27 in many ways [48].

The decrease in weight and proliferating cell nuclear antigen is associated with the decrease in c-myc protein expression during liver regeneration. Moreover, the cell cycle regulating protein p53 and the number of cells in the $\mathrm{G}_{2}$ phase of the cell cycle was greatly reduced. Consequently, c-myc is considered a strong positive regulator of cell proliferation. Besides, c-myc antisense was found to limit liver regeneration in rats [24,26].

Similarly, in kidney tissue, the c-mycgene was found to be activated in kidney tubule cells during regeneration and after folic acid-induced renal injury in vivo [49]. C-myc was also found to promote protein biosynthesis where the protein synthesis was higher three times in fibroblasts overexpressing c-myc than that in their naïve cell lines. C-myc exerts this action by regulating ribosome transcription and biogenesis; also, c-myc works in coordination with nuclear RNA polymerases (RNA pol I and III) to regulate ribosome biogenesis and translation. 
Besides, the transcription of ribosomal RNA was stimulated by c-myc, which activates protein synthesis [50].

In the present investigations, TAA acute toxicity resulted in a significant increase of TNF- $\alpha$ gene expression levels in liver tissue as well as elevated plasma levels, while this increase was significantly downregulated upon chitosan-treatment both as protective and curative treatments as compared to the TAA-intoxicated group. This finding is in accordance with the previous observation of Park et al. [51], who reported an ameliorating effect of chitosan on TNF- $\alpha$ level. Zhang et al. [52] reported that cross-linked carboxymethyl chitosan increased inflammatory factor enzymes' activities at the beginning of the treatment; however, it restores them to their normal level after that. They suggested wound healing effects of cross-linked carboxymethyl chitosan through its down-regulatory effects on rats' liver enzyme activity.

TNF- $\alpha$ is produced from neuronal cells, fibroblast, lymphoid cells, mast cells, endothelial cells, and macrophages. TNF- $\alpha$ mediates its pro-inflammatory and pro-apoptotic effects through the interaction with their membrane receptors (TNF-R1 and TNF-R2). Both receptors mediate two different signaling pathways, and the activation of one is accompanied by the inactivation of the other [51].

Our results suggest a positive role by chitosan in tissue regeneration which is in accordance with Shilapa et al. [53], who found that treating partially hepatectomized rats with chitosan nanoparticles and gamma-aminobutyric acid elevated tritiated thymidine uptake compared with partially hepatectomised groups without nanoparticle treatment. The overall result of chitosan nanoparticles treatment coupled with gamma-aminobutyric acid is the enhancement of hepatocyte regeneration and decreased cell death compared to liver hepatectomized rats. The current results are also in accordance with Chen et al. [54], who reported that chitosan nanoparticles enhanced liver regeneration in rats suffering from acute liver failure. The matrix binding capacity of chitosan enables the growth and activation of macrophages which is necessary for tissue regeneration. A wound conducted in a dog animal treated with chitosan showed complete curing after three weeks. However, in the control group treated with saline, only the curing process endures four weeks. In chitosan treated group, a keratin layer was formed as evidence for connective tissue regeneration. Besides, a collagen fiber network was formed to guard wound neovasculature [55].

In the current study, the histological finding revealed a deteriorated liver tissue pattern in the TAA group; however, this pattern was ameliorated greatly in the chitosan protective group and somehow in the curative chitosan group.

\section{Conclusions}

It is concluded that chitosan can enhance liver regeneration in TAA-induced liver toxicity, either as a curative or proliferative. Moreover, it showed an anti-inflammatory effect as it reduced the level of TNF- $\alpha$, both at gene and protein levels. In contrast, chitosan increased the gene expression of survivin and c-myc, which are enhancers of cell proliferation. Further studies could be conducted to elucidate the exact mechanism by which chitosan affects c-myc, survivin, and TNFC- $\alpha$ gene expression. Consequently, chitosan is recommended to be used in liver diseases where tissue regeneration is needed. 


\section{Funding}

This research received no external funding

\section{Acknowledgments}

This research has no acknowledgment.

\section{Conflict of interests}

The authors declare that there are no conflicts of interest.

\section{References}

1. Alboraie, M.; Youssef, N.; Sherief, A.F.; Afify, S.; Wifi, N. M. et al. Egyptian liver library: An indexed database for liver disease evidence in Egypt. Arab $J$ Gastroenterol 2019,20,109-113, https://doi.org/10.1016/j.ajg.2019.05.004.

2. Hassan, A.; Abouseif, H.; El Hosseiny, M.; Anwar, W. A. Mortality associated with liver diseases in Egypt (1986- 2005).Eur J Oncol 2011,16, 211-220.

3. Asrani, S.; Devarbhavi, H.; Eaton, J.; Kamath, P.K. Burden of liver diseases in the world. (2018) JHepato l2018,70, https://doi.org/10.1016/j.jhep.2018.09.014.

4. Abdellatif, H.; Shiha, G. Liver Regeneration: Summary Of Involved Cell Types. J Stem Cell Regen Biol 2017, 3,1-5,https://doi.org/10.15436/2471-0598.17.021.

5. Hu, J.; Srivastava, K.; Weiland, M.; Runge, A.; Mogler, C. et al. Endothelial cell-derived angiopoietin as a spatiotemporal rheostat.Science 2014,343, 416-419, https://doi.org/10.1126/science.1244880.

6. Liao, F.;Shieh, Ma.; Chien, N.Y. Chitosan supplementation lowers serum lipids and maintains normal calcium, magnesium, and iron status in hyperlipidemic patients. Nutr Res 2007, 27, 146151.https://doi.org/10.1016/j.nutres.2007.01.009.

7. Liu, S.H.; Chen, R..Y.; Chiang, M.T. Effects and Mechanisms of Chitosan and Chitosan Oligosaccharide on Hepatic Lipogenesis and Lipid Peroxidation, Adipose Lipolysis, and Intestinal Lipid Absorption in Rats with High-Fat Diet-Induced Obesity. Int. J. Mol. Sci 2021, 22, https://doi.org/10.3390/ijms22031139.

8. Krithiga, N.; Jayachitra, A.; Rajalakshmi, A. Antioxidant activity of the chitosan extracted from shrimp exoskeleton. Middle East J. Sci. Res 2013, https://doi.org/10.5829/idosi.mejsr.2013.16.10.12033.

9. Abo Zaid, O. R.; Abd El-hamid, O .M.; Atwa, S. A .E. Hypolipidemic and anti-inflammatory effect of chitosan in experimental induced non -alcoholic fatty liver disease in rats. BVMJ 2015,28,155-165.

10. Sarkar, M. K.; Sil, P. C. Hepatocytes are protected by herb Phyllanthusniruri protein isolate against TAA toxicity. Pathophysiology 2007, 14, 113-120,https://doi.org/10.1016/j.pathophys.2007.08.001.

11. Jhaveri, J.; Raichura, Z.; Khan, T.; Momin, M.; Omri, A. Chitosan Nanoparticles-Insight into properties, Functionalization and Applications in Drug Delivery and Theranostics. Molecules 2021, 26, 272,https://doi.org/10.3390/molecules 26020272

12. Abo zaid, A ; El-sonbaty, S. M .; El-sonbaty. Antioxidants and hepatoprotective effects of chitosan nanoparticles against hepatotoxicity induced in rats. BVMJ 2019, https://doi.org/10.21608/.111628.

13. Kean, T.; Thanou,M. Biodegradation,biodistribution and toxicity of chitosan.Adv Drug Deliv Rev 2010,62, 3-11, https://doi.org/10.1016/j.addr.2009.09.004.

14. Zaleska, A. P.; Gorska, J. W.; Sobezak, J.; Hupka, J. Thioacetamid and thiourea impact on visible light activity of TiO2, Applied Catal. B: Environ 2007, 76, 1-8, https://doi.org/10.1016/j.apcatb.2007.05.005.

15. Li, X; Zhang, H.; Pan, L.; Zou, H.; Miao, X.; Cheng, J.; Wu, Y. Puerarin alleviates liver fibrosis via inhibition of the ERK1/2signaling pathway in thioacetamide-induced hepatic fibrosis in rats. Experimental therapeutic medicine 2019, 18, 133- 138, https://doi.org/10.3892/etm.2019.7534.

16. Wang, M. E.; Chen, Y C.; Chen, I. S.; Hsieh, S .C.; Chen, S. S. et al. Curcumin protects against thioacetamideinduced hepatic fibrosis by attenuating the inflammatory response and inducing apoptosis of damaged hepatocytes. J. Nutr. Biochem 2012, 23, 1352-1366, https://doi.org/10.1016/jnutbi.2011.08.004.

17. Elnfarawy, A. A; Nashy, A.E.; Abozaid, A.M.; Komber, I.F.; Elweshahy R.H.; Abdelrahman R.S. Vinpocetine attenuates thioacetamide-induced liver fibrosis in rats. Human \& experimental toxicolog 2020, https://doi.org/10.1177/0960327120947453. 
18. Baskaran, Y.; Periyasamy, V.; Venkatraman, A. C.Investigation of antioxidant, anti-inflammatory and DNAprotective properties of eugenol in thioacetamide-induced liver injury in rats. Toxicology 2010,268, 204-212, https://doi.org/10.1016/j.tox.2009.12.018.

19. Yang, H. Y. ;Kim , K.S. ;Lee,Y. H.;Park, G.H; Kim, J.H;Lee, S. Y.;Kim ,Y. M.; Kim, I.S.; Kacew, S.; Lee, M.B.; Kwak, J.H.; Yoon, K.; Kim, H. S. Dendropanax morbifera ameliorates thioacetamide-induced hepatic fibrosis via TGF- $\beta 1 /$ Smads Pathways.Int J Biol Sci 2019,15, 80-811, https://doi.org/10.7150/ijbs.30356.

20. Ramez, A.E.;Barhoma, M.D. Possible Therapeutic Effect of Crocin on Thioacetamide-Induced Liver Injury in Male Albino Rats. Med. J. Cairo Univ 2018, 86, 281-287, https://doi.org/10.21608/mjcu.2018.55104.

21. Sayan, M.; Karabulut, D.; Ozdamar, S. Assessment of the protective and therapeutic effect of melatonin against thioacetamide-induced acute liver damage. $J$ Biochem Mol Toxicol 2020, 34, https://doi.org/10.1002/jbt.22450.

22. Su, Z.; Yang, Z.; Xu, Y.; Chen, Y.; Yu .Q. Apoptosis, autophagy, necroptosis, and cancer metastasis. Mol Cancer 2015, 14, https://doi.org/10.1186/s12943-015-0321-5.

23. Altieri, D.C. Validating survivin as a cancer therapeutic target.Nat Rev Cancer 2003, 3,46-54, https://doi.org/10.1038/nrc968.

24. Arora, V.; Derek, C.; Knap, P.; Barbara, L.; Smit, H. et al. c-mycantisense limits rat liver regeneration and indicates role for c-mycin regulating cytochrome P-450 3A activity. J. Pharmacol. Exp Ther 2000,292,921928.

25. Sanders, J.A.; Schorl, C.; Ajay Patel, A.; Sedivy, J. M.; Gruppuso, P. A. Postnatal liver growth and regeneration are independent of c-myc in a mouse model of conditional hepatic c-myc deletion. BMC Physiology 2012,12, https://doi.org/10.1186/1472-6793-12-1.

26. Melnik, S., Nadine Werth, N., Boeuf, S, Hahn, E., Gotterbarm, T, Anton, M.; Richter, W. Impact of c-MYC expression on proliferation, differentiation, and risk of neoplastic transformation of human mesenchymal stromal cells. Stem Cell Research \& Therapy 2019,10,https://doi.org/10.1186/s13287-019-1187-z.

27. Schwabe, R. F.; Brenner, D.A. Mechanisms of Liver Injury.TNF- alpha induced liver injury: role of IKK, JNK, and ROS pathways.Am J PhysiolGastrointest Liver Physiol 2006, 290, https://doi.org/10.1152/ajpgi.00422.2005.

28. Mercogliano, M.F.; Bruni, S., Mauro, F.; Elizalde, P.V.; Schillaci, R.Harnessing Tumor Necrosis Factor Alpha to Achieve Effective Cancer Immunotherapy. Cancers 2021,13, 564. https://doi.org/10.3390/cancers13030564.

29. Eftekhari, R. B.; Maghsoudnia, N.; Samimi, S. Application of chitosan in oral drug delivery. In Functional chitosan; Sougata Jana, Subrata Jana; Springer, Singapore, 2019, Volume 1, 43-73, https://doi.org/10.1007/978-981-15-0263-7-2.

30. Mustafa, H. N.; Sally, A.; ElAwdan, B.; Gehan, A. Protective role of antioxidants on thioacetamide-induced acute hepatic encephalopathy: Biochemical and Ultrastructural study, Tissue Cell 2013, 45, 350- 362, https://doi.org/10.1016/j.tice.2013.06.001.

31. Slaoui, M.Histopathology procedures: from tissue sampling to histopathological evaluation. In Gautier JC. (eds) Drug Safety Evaluation. Methods in Molecular Biology (Methods and Protocols), Humana Press, 2019, Volume 691, 69 -82, https://doi.org/10.1007/978-1-60761-849-2_4.

32. Abu Rmilah, A.; Zhou, W.; Nelson, E.; Lin, L.; Amiot, B. et al.Understanding the marvels behind liver regeneration.Wiley Interdiscip Rev Dev Biol 2019, 8, e340, https://doi.org/10.1002/wdev.340.

33. Rajkapoor, B.; Venigopal, Y.; Anbu, J.; Harikrishnan, N.; Gobinath, M. et al. Protective effect of Phyllanthuspolyphyllus on acetaminophen-induced hepatotoxicity in rats. Pak JPharm Sci 2008, 21, 57-62.

34. El-Masry, H. M.A.; Mahmoud, A.A.H. Free Radicals and Antioxidants in Diseased Neonates.Annals of Neonatology Journal 2021,3, 8-23, https://doi.org/10.21608/anj.2020.131987.

35. Nozu, F.; Takeyama, N.; Tanaka, T. Changes of hepatic fatty acid metabolism produced by chronic TAA administration in rats. Hepatology 1992, 15, 1099-1100, https://doi.org/10.1002/hep.1840150621.

36. Yamate, J.; Izawa, T.; Kuwamura, M. Histopathological Analysis of Rat Hepatotoxicity Based on Macrophage Functions: in Particular, an Analysis for Thioacetamide-induced Hepatic Lesions.Food Saf 2016, 4, 61-73, https://doi.org/10.14252/foodsafetyfsci.2016012.

37. El-Baz, F.K.; Salama, A.; Ali, S.; Elgohary R. Haematococcus pluvialis carotenoids enrich fraction ameliorate liver fibrosis induced by thioacetamide in rats: modulation of metalloproteinase. BioMed Res Int 2021, https://doi.org/10.1155/2021/6631415. 
38. Jain, K. N.; Singhai, A.K. Protective effects of Phyllanthusacidus (L.) Skeels leaf extracts on acetaminophen and TAA induced hepatic injuries in Wistar rats. Asian Pac JTrop Med 2011, 4, 470-474, https://doi.org/10.1016/s1995-7645(11)60128-4.

39. Ansil, P. N.; Nitha, A.; Prabha, S. P.; Wills, P. J.; Jazaira, V. et al. Protective effect of Amorphophalluscampanulatus (Roxb.) Blume. Tuber against thioacetamide induced oxidative stress in rats. Asian Pac J Trop Med 2011, 4,870-7,https://doi.org/10.1016/S1995-7645(11)60211-3.

40. Osama, A.; Mohamed, E.; Engy, R.; Mohammed, F. H.; Abu Ghanema, W.A. Hepatoprotective and Antioxidant Effects of Pomegranate Against ThioacetamideToxicity in Rats. AVAS 2016, 3, 28-41.

41. Begum, Q.; Noori, S.; Mahboob, T. antioxidant effect of sodium selenite on thioacetamide-induced renal toxicity.Pak.J.Biochem.Mol.Biol 2011,44, 21-26.

42. Mohamed, N. E. Effect of Chitosan on Oxidative Stress and Metabolic Disorders Induced In Rats Exposed to Radiation. Am. J. Sci 2011, 7.

43. Gassmann, R.; Carvalho, A.; Henzing, A. J.; Ruchaud, S.; Hudson, D. F. et al. Borealin: a novel chromosomal passenger required for stability of the bipolar mitotic spindle. J Cell Biol 2004, 166 179-191, https://doi.org/10.1083/jcb.200404001.

44. Wheatley, S. P.; Altieri, D. C. Survivin at a glance. J Cell Sci.2019, 132, https://doi.org/10.1242/jcs.223826.

45. Garg, H.; Suri, P.; Jagdish, C.; Gupta, G. P. Talwaret al. survivin: a unique target for tumor therapy. Cancer Cell Int2016, 49, 16-49, https://doi.org/10.1186/s12935-016-0326-1.

46. Hagemann, S.; Wohlschlaeger, J.; Bertram, S.; Levkau, B.; Musacchio, A. et al. Loss of survivin - influences liver regeneration and is associated with impaired Aurora B function. Cell Death Differ 2013, 20, 834-844, https://doi.org/10.1038/cdd.2013.20.

47. Pelengaris, S.; Khan, M.; Evan, G. c-MYC: more than just a matter of life and death, Nat Rev Cancer 2002,2, 764-76, https://doi.org/10.1038/nrc904.

48. Gutiérrez, L.; Dolores, M.; Delgado, M .D.; Javier, L. J. MYC Oncogene Contributions to Release of Cell Cycle Brakes.Genes 2019, 10, 244; https://doi.org/10.3390/genes10030244.

49. Asselin, C.; Marcu, M.K.Mode of c-myc gene regulation in folic acid induced kidney regeneration. Oncogene Res 1989, 5, 67-72.

50. Chen, B. J.; Wu, Y. L.; Tanaka, Y.; Zhang, W. Small Molecules Targeting c-Myc Oncogene: Promising AntiCancer Therapeutics. Int. J. Biol. Sci 2014,10, 1084-96, https://doi.org/10.7150/ijbs.10190.

51. Park, J. W.; Jeong, G.; Kim, S. J.; Kim, M. K.; Park, S. M. Predictors reflecting the pathological severity of non-alcoholic fatty liver disease comprehensive study of clinical, immune histochemical findings in younger Asian patients. J Gastroenterolhepatol 2007, 22, 491-497, https://doi.org/10.1111/j.14401746.2006.0758.X.

52. Zhang, W.; Xin, Y.; Yin, B.; Ye, G.L.; Wang, J.X. et al. Synthesis and properties of cross-linked carboxymethyl chitosan and its hemostatic and wound healing effects on liver injury of rats, J BiomaterAppl 2019, 34, 442-450, https://doi.org/10.1177/0885328219852888.

53. Joy, S.; George, N.; Nandhu, M.S.; Paulose, C. Evaluation of GABA-chitosan nanoparticle-induced cell signaling activation during liver regeneration after partial hepatectomy. J NanosciNanotechnol 2012, 12, 6145-55, https://doi.org/10.1166/jnn.2012.6194.

54. Chen, Z.; Chang, R.; Guan, W.; Cai, H.; Tang, F. et al. Transplantation of porcine hepatocytes cultured with polylactic Acid-o-carboxymethylated chitosan nanoparticles promotes liver regeneration in acute liver failure rats. J Drug Deliv 2011, 797503, https://doi.org/10.1155/2011/797503.

55. Rodríguez-Vázquez, M.; Vega-Ruiz, B.; Ramos-Zúñiga, R.; Saldaña-Koppel, D.A. Quiñones-Olvera, L.F. Chitosan and Its Potential Use as a Scaffold for Tissue Engineering in Regenerative Medicine. Biomed Res Int 2015, 821279, https://doi.org/10.1155/2015/821279. 